\title{
Effects of different solid carbon sources on activated sludge denitrification performance under different $\mathrm{PH}$ conditions
}

\author{
Yufeng Xie ${ }^{1, a}$, Yan Fan ${ }^{2, b}$, Wenjing Li ${ }^{1, c}$, Ya Zhang ${ }^{1, d}$ \\ ${ }^{1}$ Nanjing Institute of Environmental Sciences, MEP, Nanjing 210042, China; \\ ${ }^{2}$ College of Resources and Enviromental Sciences, Nanjing Agricultural University, Nanjing 210095, \\ China. \\ apkuyufeng@163.com, baby656566897@qq.com, Iwj901026@163.com, \\ dhenanzhangya@163.com
}

Keywords: activated sludge; solid carbon source; denitrification; nitrate nitrogen;PH.

Abstract. To learn the denitrification performance of activated sludge, the study selected waste newspaper(Short for PAP), yellow leaves of the Chinese parasol(Short for LEA), polylactic acid(Short for PLA), polyhydroxyalkanoates(Short for PHA) as solid carbon sources, and compared the effects of such four kinds of materials on sludge denitrification under different $\mathrm{pH}$ conditions. The study found that there was strong adaptability to $\mathrm{pH}$ when these solid carbons were used as carbon sources. When $\mathrm{pH}$ value is between 4.5 and 9.5, the removal rate of nitrate nitrogen does not change much, and the nitrite nitrogen also does not change much except using waste newspaper.

\section{Introduction}

With the increase of China's population, sewage discharge is increasing, and the unqualified sewage treatment makes the eutrophication become more and more serious, the nitrate content in the groundwater is increasing year by year, all of the reasons make the nitrate content become the main pollution indicators of groundwater. Based on the pollution of nitrate, more strict regulations were made to control the nitrogen and phosphorus emissions in the sewage treatment[1-4]. At present, due to the lack of carbon sources, how to control the content of nitrate in the second level sewage treatment becomes a problem to be solved urgently[5-7].

Generally, the denitrification process is used to remove the nitrate[8]. This process needs to be carried out under anoxic conditions, so we need to provide adequate organic carbon source to ensure that the reaction proceeded smoothly[9]. In recent years, many researchers are committed to looking for cheap, non-toxic, no secondary pollution, and economic and practical carbon source to solve such problem in sewage treatment[10-12]. But most of the researches are focused on methanol, ethanol, glucose and other liquid organic carbon source. In effect, these liquid carbon sources have obvious effect, but the high cost makes them unsuitable to widely use in wastewater treatment[13-19].

Domestic and foreign scholars had compared the traditional and non traditional external carbon source many times[20,21]. Nowadays, solid carbon source, which can sustained release and are cheap, has become a hotspot[22]. In general, the solid carbon source can be used in denitrification are divided into two kinds, one of them is natural material which is rich in cellulose, such as rice husk, straw[23-25], waste paper, cotton[26], the other is the synthetic materials, such as PHAs, PBS (poly-butylene-succinate), PCL (polycaprolactone) [27], PLA, etc. PHAs and PLA are synthetic biodegradable materials and natural polymers that are produced by microorganisms[28], their degradation products can enter the ecological cycle completely, and do not cause any pollution[29]. Compared with the liquid carbon source, the solid carbon source is more easy to control, and it will not affect the quality of effluent nitrate nitrogen [30].

The environmental factors can also affect the removal of nitrate nitrogen in sewage, such as temperature, $\mathrm{pH}$ value, and so on[31]. The research has found, temperature changes will have a great effect on denitrifying bacteria[32]. So researching the effect on activated sludge denitrification performance by adding different solid carbon sources under different environmental conditions can be used to guide the practical application, and it has a great practical significance. In order to provide the basis for the practical application of solid-phase denitrification, this experiment selects the waste 
newspaper, leaf, PLA, and PHA as solid carbon sources to explore the effects of environmental conditions on denitrification of activated sludge under different $\mathrm{pH}$ value condition.

\section{Materials and Methods}

Experimental Materials. Ordinary waste newspaper (PAP); natural shedding leaves of phoenix tree (LEA); polylactic acid (PLA); polyhydroxyalkanoates (PHA). Potassium nitrate, sodium nitrate, potassium dihydrogen phosphate, sulfanilic acid, hydrochloric acid naphthalene ethylenediamine, concentrated sulfuric acid and other common laboratory medicine, analysis of pure.

The activated is taken from a CAST aeration tank of the Xianlin Sewage treatment plant in Nanjing (sludge concentration is $6000 \mathrm{mg} / \mathrm{L}$ ); the waste paper is the ordinary discarded newspapers; yellow leaves of phoenix tree were collected from the campus of the Nanjing Agricultural University in autumn; PLA, PHA materials were purchased from a domestic company of biological materials, their particle diameter are about $0.3 \mathrm{~cm}$.

The experimental water was the tap water with potassium nitrate and potassium dihydrogen phosphate, the concentration of nitrate nitrogen was $50 \mathrm{mg} / \mathrm{L}$, and $\mathrm{P}$ concentration was $10 \mathrm{mg} / \mathrm{L}$.

Experimental Methods. 1)Pretreatment of carbon source materials. Wash the waste newspapers and sycamore leaves and dry naturally, and then cut them into pieces that are less than $1 \mathrm{~cm}$ wide and long. After that, put them into the wide mouth bottle or ziplock bag, and keep it in a desiccator in reserve. 2) Domesticated activated sludge. Put the activated sludge into the incubator, add nutrient solutionthe with the concentration of potassium nitrate and potassium dihydrogen phosphate for 5:1 and four kinds of solid carbon source materials, the water retention time is $24 \mathrm{~h}$; change the water regularly, and monitor the concentration of effluent nitrate nitrogen. When the concentration of effluent nitrate nitrogen tend to stable,we can start the experiment. 3) Effects of environmental conditions on denitrification. We study the effects of temperature and $\mathrm{pH}$ by batch experiments. Put the waste newspapers, leaves, PLA, PHA in the same weight (1g) into a $250 \mathrm{~mL}$ conical flask, and the vacuity contrast group has no carbon source. Then $100 \mathrm{~mL}$ water and activated sludge should be added to each conical flask, the activated sludge concentration is about $1 \mathrm{~g} / \mathrm{L}$. When all are ready, we put them into the constant temperature incubator for culturing. Regulate $\mathrm{pH}$ by $\mathrm{HCl}$ and $\mathrm{NaOH}$ solution (the six groups of $\mathrm{pH}$ gradient are 4.5, 5.5, 6.5, 7.5, 8.5, 9.5).

Analysis Methods. With regard to the water samples of supernatant, nitrate spectrophotometric is determined by UV Spectrophotometry; nitrite nitrogen is determined by naphthyl ethylenediamine dihydrochloride Spectrophotometric; TP is determined by potassium persulfate digestion ammonium molybdate spectrophotometric; COD is determined by digestion colorimetry; $\mathrm{pH}$ is determined by $\mathrm{pH}$ meter. The spectrophotometer is Shengaohua 6B-1800 multi- parameter water quality analyzer, and the digestion instrument is Shengaohua 6B-30 double intelligent digestion instrument.

\section{Results Analysis}

Decay of Nitrate Nitrogen. As shown in Figure 1, when $\mathrm{pH}$ between 4.5 and 9.5, the nitrate removal of four materials emerge as a flattening of the curve. Nitrate removal changes little despite the ups and downs at different $\mathrm{pH}$ values, indicating that the change of $\mathrm{pH}$ has little effect on denitrification rate, and that denitrifying bacteria could adapt to a wide range of $\mathrm{pH}$.

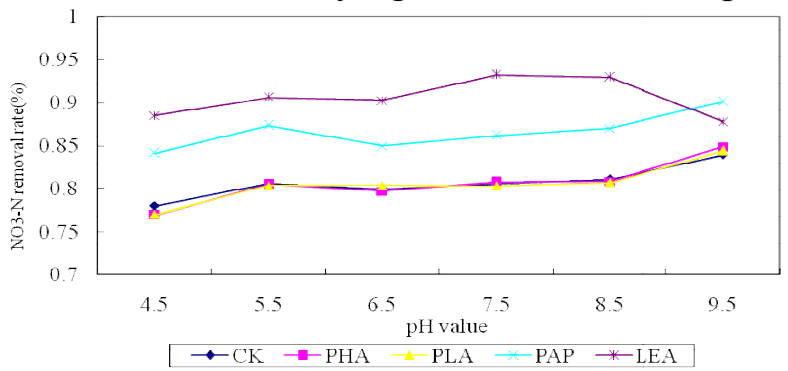

Figure 1 Nitrate Removal under Different $\mathrm{pH}$

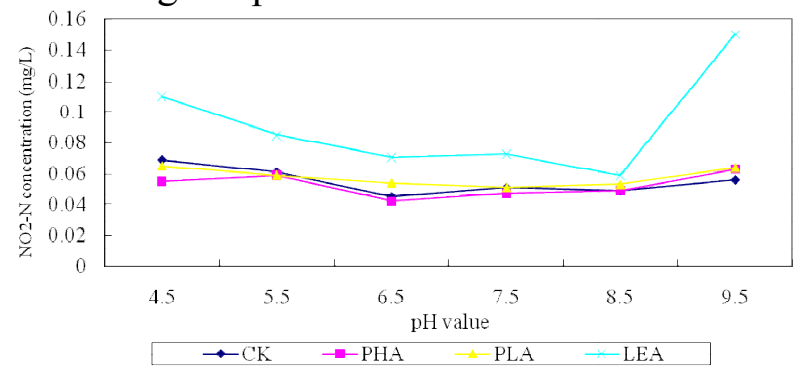

Figure 2 NO2-N Change under Different $\mathrm{pH}$ 
Nitrite Accumulation. Accumulation of nitrite at different $\mathrm{pH}$ values showed a difference. Shown in Figure 2, the $\mathrm{pH}$ in the range of 4.5 to 6.5, PHA, PLA effluent material nitrite concentration decreases with increasing $\mathrm{pH}$ in the range 6.5 to 9.5, PHA, PLA material nitrosyl state water nitrogen increases with increasing $\mathrm{pH}$. Indus leaves nitrite concentration of 8.5 minimum, 9.5 increased significantly when the $\mathrm{pH}$, and the large number of newspapers nitrite accumulation seen from Table 3 , the maximum concentration of $1.3 \mathrm{mg} / \mathrm{L}(\mathrm{pH} 5.5$ ), a minimum of $0.51 \mathrm{mg} / \mathrm{L}(\mathrm{pH} 9.5)$.

Cumulative of COD. In figure 3, the newspaper at $\mathrm{pH} 5.5$ can release most carbon, and at $\mathrm{pH} 7.5$ least; PHA's ability to release carbon relatively stable under different $\mathrm{pH}$ conditions; PLA to release carbon capacity under different $\mathrm{pH}$ conditions showed irregular changes. Whether this is an error generated during the determination or not remains to further experiment. The ability to release carbon and Indus leaves under different $\mathrm{pH}$ conditions are much higher than other materials, as shown in Table 4, the maximum value of $1226.1 \mathrm{mg} / \mathrm{L}$ ( $\mathrm{pH} 9.5$ ), minimum value of $540.5 \mathrm{mg} / \mathrm{L}$ ( $\mathrm{pH} 7.5$ ).

Figures PH Changes after Reactions. From Figure 4, we found that the water $\mathrm{pH}$ range of 4.5 to 9.5 , but $\mathrm{pH}$ of effluent $\mathrm{pH}$ close to the optimum changed by denitrification. When the inflow is acidic $\mathrm{pH}$, after denitrification $\mathrm{pH}$ values become slightly acidic. When inflow $\mathrm{pH}$ is alkaline, the $\mathrm{pH}$ values become alkaline after denitrification. Denitrification has resorted to effluent $\mathrm{pH}$ values closer to neutral for four materials.

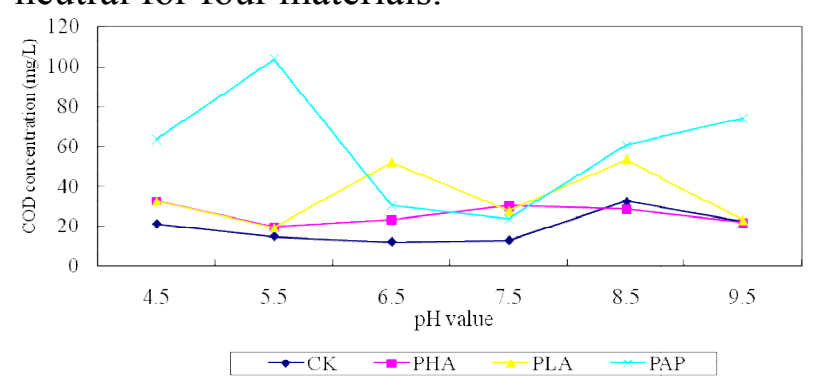

Figure 3 COD Change under Different $\mathrm{pH}$

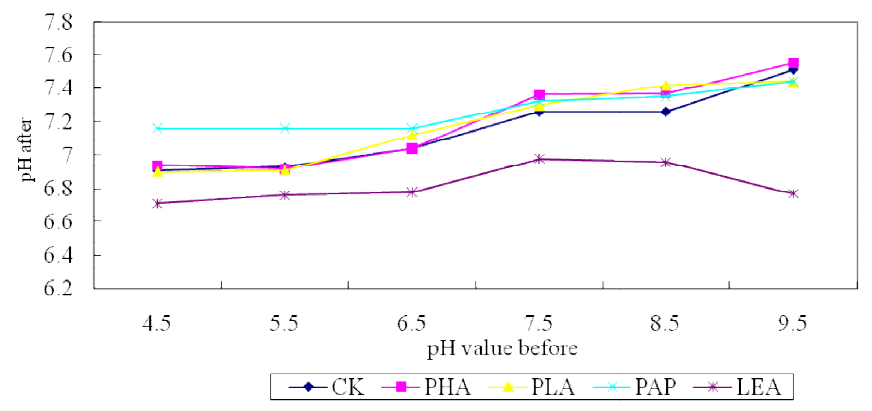

Figure $4 \mathrm{pH}$ after Denitrification Reactions

\section{Discussion and Conclusion}

Effect of Temperature on Denitrification. Combined with the removal of nitrate and nitrite nitrogen accumulation of view, resulted the ideal rate of denitrification at 25 centigrade, and COD in water is higher. Newspapers as quick release carbon material that can quickly provide carbon,Its denitrification rate is the highest in 35 centigrade, however, nitrite accumulation rate is much higher than other materials, andas the solid carbon dosing need to address these issues.Leaves can provide a lot of carbon for the denitrification, anddenitrification rate at 25 centigrade is better,but it is likely to cause a massive accumulation of phosphorus in the water, resulting in secondary pollution.

\section{Conclusion}

Among the four kinds of materials (PAP, LEA, PHA, PLA), newspapers releasing carbon fast and easy to cause the accumulation of nitrite, and not suitable as a secondary treatment of sewage plus solid carbon source;platanusorientalis fallen leaves can provide a lot of carbon source,but it probably increase the phosphorus content,so it is not suitable for use as a carbon source; PHA and PLA will not cause secondary pollution, and have a slow-release effect, but their utilization needs further experimental studies in order to obtain data for reference.

\section{Acknowledgements}

This work was financially supported by Major Science and Technology Program for Water Pollution Control and Treatment of China (2012ZX07506-007) and Jiangsu Environmental Protection Scientific Research Project (2012014). 


\section{References}

[1] J.S. Cao, L.H. Hou, et al.: Chinese Journal of Environmental Engineering Vol. 7(6) (2013), p.2013-2018.(in Chinese)

[2] Z.X. Fan, J.L. Wang: Environmental Science Vol. 30(8) (2009),p.2315-2319. (in Chinese)

[3] SEPA: The 2006 China environmental bulletin.(China Environmental Science Press, China 2007) (in Chinese)

[4] H. Sun, X.C. Zheng, et al.: China Water \&Wastewater Vol.26(13) (2010),p.82-85. (in Chinese)

[5] T.Q. Pei, X.M. Yang, et al.: Industrial Safety and Environmental Protection Vol. 39(9) (2013),p.32-34. (in Chinese)

[6] C. Su, R.W. Puls: Chemosphere Vol. 66(1) (2007),p.91-98.

[7] B. Ovez, S Ozgen, et al.: Process Biochemistry Vol. 41(7) (2006),p.1539-1544.

[8] Y.M. Xu, H.T. Wu: Environmental Pollution \&Control Vol.26(6) (2004),p.409-411.(in Chinese)

[9] J.J. Wang, L. Ren, et al.: Journal of EMCC Vol. 22(6) (2012),p.41-43. (in Chinese)

[10] H. Wen, Y.F. Chen, et al.: Acta Scientiae Circumstantiae Vol.31(3) (2011),p.499-504. (in Chinese)

[11]D.W. Blowes, W.D. Robertson, et al:: Journal of Contaminant Hydrology Vol. 15 (1994),p.207-221.

[12]W.D. Robertson, D.W. Blowes, et al.: Groundwater Vol.38(5) (2000),p.689-695.

[13]J.F. Xiong, H. Xu, et al.: Environmental Science Vol.33(11) (2012),p.4057-4061. (in Chinese)

[14]J.C. Akunna, C. Bizeau C, et al.: Water Research Vol. 27 (8) (1993),p.1303-1312.

[15]S. Fass, V. Ganaye, et al.: Environmental Technology Vol. 15(5) (1994),p.459-467.

[16]Y.T. Xu: Environmental Science Vol. 8(3) (1996),p.257-269.

[17]H. Rustige,E. Ndde: Water Science and Technology Vol. 56(3) (2007),p.125-133.

[18]M. Shrimali, K.P. Singh: Environmental Pollution Vol. 112(3) (2001),p.351-359.

[19]Y. Ding, X.S. Song, et al.: Environmental Pollution \&Control Vol. 33(12) (2011),p.65-69. (in Chinese)

[20]X.C. Zheng, J. Li, et al.: Water \&Wastewater Engineering Vol. 35(6) (2009),p.24-28. (in Chinese)

[21] Q.L. Yang, X.Y. Xi, et al.: China Water \& Wastewater Vol. 27(3) (2011),p.106-108. (in Chinese)

[22]Y. Li, M. Zhang, et al.: Journal of Wuhan University of Technology Vol. 32(6) (2010),p.27-31. (in Chinese)

[23]M.I.M. Soares, A. Abeliovich: Water Research Vol. 32(12) (1998),p.3790-3794.

[24]S. Aslan, A. Trkman. Water Sci Technol Vol. 48(11-12) (2003),p.489-495.

[25]L. Shao, Z.X. Xu, et al.: Environmental Science Vol. 30(5) (2009),p.1414-1419. (in Chinese)

[26]Z.F. Jin, Y.X. Chen, et al.:Journal of Agro-Environment Science Vol. 23(3) (2004),p.512-515. (in Chinese)

[27]Y. Honda, Z. Osawa: Polym Degrad Stab Vol. 76 (2002),p.321-327.

[28]H.J. Cao, J. Chen, et al.: China Environmental Science Vol.17(4)(1997),p.330-334.(in Chinese)

[29]C.H. Han, Z.G. Meng: China Water \& Wastewater Vol.22(18) (2006),p.4-7. (in Chinese) 
[30]T. Su, Z. Fan: Northern Environment Vol.23(6) (2011),p.138-141. (in Chinese)

[31]C.Y. Lee, H.S. Shin, et al: Water Science and Technology Vol.47(1) (2003),p.159-165.

[32]L. Xie, J.R. Chen, et al.: Journal of Bioscience and Bioengineering Vol.113(6) (2012),p.759-764. 